\title{
Folate Hydrolase 1 Measurement
}

National Cancer Institute

\section{Source}

National Cancer Institute. Folate Hydrolase 1 Measurement. NCI Thesaurus. Code C132431.

The determination of the amount of folate hydrolase 1 in a biological sample. 